Editorial

\title{
Energy Dissipation and Vibration Control: Modeling, Algorithm, and Devices
}

\author{
Gangbing Song ${ }^{1,2, *}$, Steve C. S. Cai ${ }^{3}$ and Hong-Nan $\mathrm{Li}^{2}$ \\ 1 Department of Mechanical Engineering, University of Houston, Houston, TX 77004, USA \\ 2 School of Civil Engineering, Dalian University of Technology, Dalian 116023, China; hnli@dlut.edu.cn \\ 3 Department of Civil and Environmental Engineering, Louisiana State University, \\ Baton Rouge, LA 70803, USA; cscai@lsu.edu \\ * Correspondence: GSong@UH.EDU; Tel.: +1-713-743-4525
}

Received: 31 July 2017; Accepted: 2 August 2017; Published: 7 August 2017

The topic of vibration control and energy dissipation is among the oldest and most relevant in the field of engineering. This area encompasses exciting frontier problems ranging from the control of vibrations of drill bits buried thousands of feet underground, to the isolation of towering skyscrapers against seismic excitation, and finally to the stabilization of solar panels attached to a spacecraft. Armed with an ever increasing arsenal of sensing and actuation technologies and theoretical progress, a vibrant community of researchers have gathered to tackle some of the world's toughest challenges in vibration control and energy suppression problems.

While this issue is not all-inclusive due to the extreme breadth and depth of the field, this issue does showcase some of the state-of-the-art in vibration control and energy dissipation. Specifically, topics in this issue cover: "Evaluation of a Simplified Method to Estimate the Peak Inter-Story Drift Ratio of Steel Frames with Hysteretic Dampers" [1], "PTMD Control on a Benchmark TV Tower under Earthquake and Wind Load Excitations" [2], "Experimental Investigation of a Base Isolation System Incorporating MR Dampers with the High-Order Single Step Control Algorithm" [3], "Integrated Design of Hybrid Interstory-Interbuilding Multi-Actuation Schemes for Vibration Control of Adjacent Buildings under Seismic Excitations" [4], "Active Vibration Suppression of a Motor-Driven Piezoelectric Smart Structure Using Adaptive Fuzzy Sliding Mode Control and Repetitive Control" [5], "Dynamic Response of a Simplified Turbine Blade Model with Under-Platform Dry Friction Dampers Considering Normal Load Variation" [6], "Preliminary Study on the Damping Effect of a Lateral Damping Buffer under a Debris Flow Load" [7], "Self-Tuning Fuzzy Control for Seismic Protection of Smart Base-Isolated Buildings Subjected to Pulse-Type Near-Fault Earthquakes" [8], "The Bivariate Empirical Mode Decomposition and Its Contribution to Grinding Chatter Detection" [9], "Optimization Design of Coupling Beam Metal Damper in Shear Wall Structures" [10], "Wind Turbine Gearbox Fault Diagnosis Based on Improved EEMD and Hilbert Square Demodulation" [11], "Investigations on the Effects of Vortex-Induced Vibration with Different Distributions of Lorentz Forces" [12], "An Experimental Validated Control Strategy of Maglev Vehicle-Bridge Self-Excited Vibration" [13], and "A Novel Hybrid Semi-Active Mass Damper Configuration for Structural Applications" [14].

This issue only provides a brief glimpse into the possibilities offered by research in vibration control and energy dissipation. As the current research builds upon the efforts of previous investigators, the results presented in this issue will now help to open the doors for increasingly advanced topics that are sure to offer benefits and push society forward.

Acknowledgments: This research was partially supported by the Major State Basic Development Program of China (973 Program, grant number 2015CB057704), Innovative research group project (grant number 51421064) and general project (grant number 51478080 and 51278084) of Natural Science Foundation of China. The authors would like to acknowledge for these financial supports. 
Conflicts of Interest: The authors declare no conflict of interest.

\section{References}

1. Kang, J.; Mori, Y. Evaluation of a Simplified Method to Estimate the Peak Inter-Story Drift Ratio of Steel Frames with Hysteretic Dampers. Appl. Sci. 2017, 7, 449. [CrossRef]

2. Lin, W.; Song, G.; Chen, S. PTMD Control on a Benchmark TV Tower under Earthquake and Wind Load Excitations. Appl. Sci. 2017, 7, 425. [CrossRef]

3. Fu, W.; Zhang, C.; Sun, L.; Askari, M.; Samali, B.; Chung, K.; Sharafi, P. Experimental Investigation of a Base Isolation System Incorporating MR Dampers with the High-Order Single Step Control Algorithm. Appl. Sci. 2017, 7, 344. [CrossRef]

4. Palacios-Quiñonero, F.; Rubió-Massegú, J.; Rossell, J.; Karimi, H. Integrated Design of Hybrid Interstory-Interbuilding Multi-Actuation Schemes for Vibration Control of Adjacent Buildings under Seismic Excitations. Appl. Sci. 2017, 7, 323. [CrossRef]

5. Lin, C.; Jheng, H. Active Vibration Suppression of a Motor-Driven Piezoelectric Smart Structure Using Adaptive Fuzzy Sliding Mode Control and Repetitive Control. Appl. Sci. 2017, 7, 240. [CrossRef]

6. He, B.; Ouyang, H.; Ren, X.; He, S. Dynamic Response of a Simplified Turbine Blade Model with Under-Platform Dry Friction Dampers Considering Normal Load Variation. Appl. Sci. 2017, 7, 228. [CrossRef]

7. Lu, Z.; Yang, Y.; Lu, X.; Liu, C. Preliminary Study on the Damping Effect of a Lateral Damping Buffer under a Debris Flow Load. Appl. Sci. 2017, 7, 201. [CrossRef]

8. Zhao, D.; Liu, Y.; Li, H. Self-Tuning Fuzzy Control for Seismic Protection of Smart Base-Isolated Buildings Subjected to Pulse-Type Near-Fault Earthquakes. Appl. Sci. 2017, 7, 185. [CrossRef]

9. Chen, H.; Shen, J.; Chen, W.; Wu, C.; Huang, C.; Yi, Y.; Qian, J. The Bivariate Empirical Mode Decomposition and Its Contribution to Grinding Chatter Detection. Appl. Sci. 2017, 7, 145. [CrossRef]

10. Zhang, Z.; Ou, J.; Li, D.; Zhang, S. Optimization Design of Coupling Beam Metal Damper in Shear Wall Structures. Appl. Sci. 2017, 7, 137. [CrossRef]

11. Chen, H.; Chen, P.; Chen, W.; Wu, C.; Li, J.; Wu, J. Wind Turbine Gearbox Fault Diagnosis Based on Improved EEMD and Hilbert Square Demodulation. Appl. Sci. 2017, 7, 128. [CrossRef]

12. Zhang, H.; Liu, M.; Fan, B.; Chen, Z.; Li, J.; Gui, M. Investigations on the Effects of Vortex-Induced Vibration with Different Distributions of Lorentz Forces. Appl. Sci. 2017, 7, 61. [CrossRef]

13. Wang, L.; Li, J.; Zhou, D.; Li, J. An Experimental Validated Control Strategy of Maglev Vehicle-Bridge Self-Excited Vibration. Appl. Sci. 2017, 7, 38. [CrossRef]

14. Demetriou, D.; Nikitas, N. A Novel Hybrid Semi-Active Mass Damper Configuration for Structural Applications. Appl. Sci. 2016, 6, 397. [CrossRef] 